The Journal of Public Space

ISSN 2206-9658

2018 | Vol. 3 n. 3

https://www.journalpublicspace.org

\title{
EDITORIAL
}

\section{The resurgence of public space: from the Charter of Athens to the New Urban Agenda}

\author{
Michael W. Mehaffy \\ KTH Royal Institute of Technology, Centre for the Future of Places, Sweden \\ michael.mehaffy@gmail.com
}

\author{
Setha M. Low \\ The Graduate Center, City University of New York, Public Space Research Group, USA \\ SLow@gc.cuny.edu
}

\begin{abstract}
This paper serves as an introduction to the December 2018 edition of The Journal of Public Space, and a reflection on the new importance of public space in international research, policy and practice. Nowhere is that more evident than in the New Urban Agenda, the ambitious new international agreement for the normative goals of urban development in the next two decades and beyond. In that document, public space is treated in no fewer than nine paragraphs - and that new emphasis constitutes a historic reversal of highly influential normative models of prior urban practice. Herein we examine the seminal 1933 Charter of Athens, and we draw out major differences between the two documents, with particular attention to urban form and public space. We conclude with an assessment of the challenges ahead for implementation, particularly as we face significant "lock in" of the older model.
\end{abstract}

Keywords: Charter of Athens, New Urban Agenda, public space, co-production, affordance

To cite this article:

Mehaffy, M. W., Low, S. (2018). The resurgence of public space: from the Charter of Athens to the New Urban Agenda. The Journal of Public Space, 3(3), I-24, DOI 10.3289 I/jps.v3i3.I I 34

This article has been reviewed and accepted for publication in The Journal of Public Space.

This work is licensed under a Creative Commons Attribution - Non Commercial 4.0

International License https://creativecommons.org/licenses/by-nc/4.0/ 


\section{Introduction}

In December 2016, the New Urban Agenda, the outcome document of the United Nations Conference on Housing and Sustainable Urban Development, also known as Habitat III, was adopted by consensus by all 193 member states of the United Nations. As such, the document represents a historic international agreement on urbanisation and urbanism for the next two decades and beyond (United Nations, 2017).

Notwithstanding this achievement, it is widely recognised that there are many challenges remaining in implementing the New Urban Agenda. For example, Joan Clos, the Secretary-General of the Habitat III conference, expressed his belief that essential knowledge about the relation of public space to buildable space must be recovered in order to proceed with implementation:

In general, the urban community has become lost in strategic planning, masterplanning, zoning and landscaping ... All these have their own purposes, of course - but they don't address the principal question, which is the relationship in a city between public space and buildable space. This is the art and science of building cities - and until we recover this basic knowledge, we will continue to make huge mistakes. (Clos, 2016)

Sociologist Richard Sennett, a collaborator with Clos in preparing a series of documents on the implementation of the New Urban Agenda called The Quito Papers (UN-Habitat, 2018), has placed considerable blame for this loss of basic knowledge at the feet of the architect Le Corbusier, who was enormously influential in formulating the urban planning practices of the last half-century:

Not only is Corbusier's architecture a kind of industrial manufacture of buildings. He has tried in the 'Plan Voisin' to destroy just that element which, as we will see, creates open-ness in a city. $\mathrm{He}$ got rid of life on the ground plane; instead, people live and work in isolation, higher up (Sennett, 2017).

Le Corbusier's project, said Sennett, was a form of over-determination of the structure of the city, comprising a "closed system," whereas cities are, and should be treated as, "open systems." For Sennett, this is a necessary change in our thinking about cities, and one that is embodied in the New Urban Agenda and its implementation.

No less crucially, this open ground plane is in fact the arena of a city's public space, whereas the higher levels of the city - and other physically segregated realms - are increasingly private spaces. As Clos suggests, the implications for the treatment of public spaces are profound.

Perhaps most crucially, however, in Le Corbusier's project, it is technical experts especially planners and designers - that are the agents of creation of a modern city. In Clos' conception, and in the New Urban Agenda, the city and the urban fabric are always co-produced by the people and place. Without this interface, integration and interplay, the city becomes a kind of lifeless machine that cannot address fundamental human needs for sociality, equality, movement, and autonomy.

In this article, then, we look more carefully at Le Corbusier's ideas, and less directly, the ideas of his influential colleagues, as they were formulated in the famous 1933 Charter of Athens - a document whose influence on modern planning practice can scarcely be under-stated (Jacobs and Appleyard, 1987). We then turn to the New Urban Agenda and 
its humanistic and social justice goals, emphasising the central role of people and their practices as integral co-producers in the planning and design process.

This analysis will proceed as a point-by-point comparison of key areas in the two texts, the 1933 Charter of Athens and the 2016 New Urban Agenda. We highlight six subject areas where there are significant divergences - the most significant between the two documents. We consider in particular the implications for the role of public space in the city and look at broader issues to be confronted in implementing the New Urban Agenda. The six subject areas are:

I. The structural relationship of the parts of the city to one another and to the whole.

2. The design of streets and the organization of types of movement and activity along them.

3. The relation of public spaces (including streets) to private spaces (including private buildings).

4. The perceived value of older parts of the city.

5. The role of technical specialists and their institutions, in relation to citizens and small organizations, as potential co-creators of the city.

6. The process of evolution and change within the city.

After comparing the differences between these subject areas in the two documents, we turn to a broader subject area that is not directly addressed in the Athens Charter but is forcefully asserted in the New Urban Agenda: the essential need for public space. We argue that public space, including certain essential characteristics, must play a central role in achieving the over-arching goal of "cities for all," social justice and social inclusion.

Above all, this public space must afford "co-production," that is, the opportunity for many people and entities operating within many scales of space and time to interact, and to produce together the structures of the city - and especially those within or adjoining its public realm. We then conclude that a co-production model of planning and design accommodates the kinds of social, physical and environmental changes that are required in this period of unprecedented urban growth, especially within rapidly urbanising regions of the developing world.

\section{The 1933 Charter of Athens}

Although today we commonly refer to the "I933 Charter of Athens," the actual printed document by that name was written by Le Corbusier and published in French ten years later (Le Corbusier, 1943). A somewhat competing document was published in English a year earlier by Harvard's Jose Luis Sert, Can Our Cities Survive? (Sert, 1942). Both documents incorporated similar material and took similar positions, largely influenced by a seminal meeting that did in fact occur ten years earlier (Gold, 1998).

This famous meeting was held by a leading group of architects known as the Congres International d'Architecture Moderne, or CIAM, a highly influential early 20th Century movement that largely set the blueprint for modern city design. Many of the document's key concepts had already emerged from a previous series of CIAM conferences, culminating in the fourth plenary conference in 1933. The meeting took place aboard a cruise ship, the SS Patris, traveling from Marseilles to Athens - the latter city giving the document its name. 
There are notable divergences and changes of emphasis between the discussions on board the SS Patris and the document a full decade later by Le Corbusier, as has been discussed extensively by Gold (1998) and others. In fact, as Gold demonstrates, the evidence shows that the outcome in 1933 was merely a series of discussion points, drafts and drawings, and not a single agreed "charter." Le Corbusier later compiled his own interpretation of the points of discussion, covering the planning of cities in an exhaustive series of 95 points - perhaps intentionally echoing Martin Luther's historic Ninety-Five Theses, the declaration that launched the Protestant Reformation.

As Gold describes, one of the most significant points of divergence is the more restrictive definition of "functionalism" given by Le Corbusier, whereas some others preferred a more generous definition that included intellectual, emotional and spiritual "functions" as well as physical ones. Le Corbusier's definition focused upon a mechanical efficiency of ordered parts that responded to the dictates of standardized production (Gold, 1998, p. 228). Underneath this technical agenda also lay a political agenda: his goal was to develop an explicit consensus between actors at the international architectural congress that included unionists, Italian fascists, collectivists and technical experts, by linking antagonistic social and political programs (Holston 1989).

In any case, it is Le Corbusier's formulation that has been recognised as the authoritative formulation of the "1933 Charter of Athens" - and it is this document that has had the most profound effect upon urban development in the following decades.

\section{The Social and Political Goals of the Athens Charter}

Le Corbusier and the CIAM movement were committed to introducing the philosophy and pragmatics of modernism, by employing Russian and European sociopolitical models through architecture and planning (Holston, 1989). Only in this way could their vision of social equality and rational social and political development be achieved. Based partly on then-current views on public health promotion, especially with the advent of dense, diverse and dirty cities posing a barrier to human well-being and technological innovations in industries including construction and design, the Athens Charter also sought to reorganize the public and private domains for social life. With this turn away from the historical and cultural patterns of cities that had evolved in often organic and interdependent ways, this new architectural and planning manifesto set out to reform not only the form of the city, but the way that citizens would socially organize, encounter one another and interact with their governmental agents. Their ideal was to eliminate and erase the preindustrial city in order to create new social and physical entities through modern architecture, and ultimately produce a new kind of city and citizen (Holston, 1989).

Interestingly, like the $2016 \mathrm{New}$ Urban Agenda, the goals of the Athens Charter were idealistic in their desire to address the social pathologies created by the form and design of the largely informal preindustrial city and the looming problems of the rapidly growing industrial areas. Similar to Haussmann (1853) who redesigned Paris by opening up broad boulevards to facilitate circulation as well as to destroy the political power of dense and socially intricate working-class neighbourhoods (Harvey, 2003), the goal of creating the "city of tomorrow" (Le Corbusier, 1924) also had revolutionary as well as capital-driven intentions. The modernism that the Athens Charter proposed was intended to produce 
a utopian future where the machine, factory and automobile as well as the house would produce human happiness.

The post-World War I ideals of CIAM held sway in the struggle to revitalize the war-torn and aging cities in Europe, to reorganize transport systems, build factories, schools and hospitals and to address the growing disparities and dislocations of the new conditions of industrial production (Harvey, 1989). According to Holston (1989), the CIAM principles consolidated ideas about the city, synthesizing anti-capitalist and egalitarian ideals and a model of the city as a machine, with ideas about building typologies and planning conventions as instruments of social and political change. Sadly, this progressive agenda was marred by a superficial and naive understanding of the nature of social relations, the importance of an organic and open plan city and the complex realities of urban life - as we will explore in more detail later.

One of the most complete examples of the impact of this manifesto was the new capital of Brasilia designed by Lúcio Costa and Oscar Niemeyer, begun in 1957. The plan drew upon the prototypes for the Athens Charter, Le Corbusier's Radiant City of 1930 and A Contemporary City for Three Million Inhabitants of 1922 (Le Corbusier, 1937). James Holston (1989) has written in detail about the struggle to build this modernist city in Brazil and how the planning and design ignored cultural and social needs and excluded the workers by building segregated towns on the periphery and creating homogeneous neighbourhoods of middle class civil servants with broad open spaces and roadways that could not be crossed and were designed at a monumental scale.

Further, as our analysis below will show in more detail, the Athens Charter model radically separated the street from home, as well as the home from work and school, disrupting the normal course and social mixing of everyday life. The consequences of this fateful segregation are evident in Brasilia. Volumes have been written about the pathology of the Brasilia plan and its aftermath (Epstein, 1968; Peattie, 1969; Holston, 1989), but the critical takeaway is that at its most extreme, this architectural manifesto, intended as a critique and a proposal to offer better housing, health and social equity to the working masses, instead created alienating spaces deprived of any social, cultural, historical or political context and framing.

\section{The Structure of the 1993 Athens Charter}

In the Athens Charter, 95 points were organized into an outline form integrating the key urban objectives of providing housing, work, recreation and transportation with a public core of administrative and civic activities:

I. Generalities: The City and Its Region

2. The Prevailing Condition of Cities: Critical Examination and Remedial Measures
a. Habitation
b. Leisure
c. Work
d. Traffic
e. The Historic Heritage of Cities

3. Conclusions: Main Points of Doctrine

Each of the sections was further organized into "observations" and "requirements." 
The resurgence of public space

Following our framework of six subject areas outlined previously, key elements of the Charter of Athens can be summarized as follows:

l. Function-based zoning.

Work, home, recreation and transport were to be segregated into zones carefully planned according to a rational scheme of spatial allocation. Further separations were to be made between office, industrial and other commercial uses. These zones were to be organized into large functional units, including pedestrian-only "superblocks".

Zoning is an operation carried out on the city map with the object of assigning every function and every individual to its rightful place. (Le Corbusier, 1943, para. 15)

and

By taking account of the key functions - housing, work, recreation - zoning will introduce $a$ measure of order into the urban territory. (Ibid.,para.8I)

\section{Functionally restricted streets.}

The use of streets as mixed public and pedestrian spaces was to be banished (expressed in Le Corbusier's famous pronouncement, "we must kill the street"). Instead, pedestrians were to be removed to their own circulation network (typically within superblocks, or in grade-separated crossings). Streets, now for vehicles only, were to be widened and spaced farther apart, with fewer intersections and access points. A functional classification system was to be introduced to allocate separate lanes and roads based on vehicle speed.

Traffic channels must be classified according to type and constructed in terms of the vehicles and speeds they are intended to accommodate. (Ibid., para. 60)

and

The first effective measure in dealing with the congested arteries would be a radical separation of pedestrians from mechanized vehicles. The second would be to provide heavy trucks with a separate traffic channel. And the third would be to envisage throughways for heavy traffic that would be independent of the common roads intended only for light traffic. (Ibid., para.60)

and

The width of the streets is inadequate... There is no uniform standard for street widths. It all depends on the number and type of vehicles they accommodate. (Ibid., para.55)

\section{Segregation of buildings.}

Buildings were no longer to line or enclose streets to form continuous urban fabric; rather, each building was to be set far back from streets, and set away from other buildings in a clear functional layout. Residents were to have access to fresh air and light afforded by tall buildings and grade-separated pedestrian paths.

The interior condition of a dwelling may constitute a slum, but its dilapidation is extended outside by the narrowness of dismal streets and the total absence of those verdant spaces, the generators of oxygen, which would be so favourable to the play of children. (Ibid., para. I0)

and 
The traditional alignment of habitations on the edges of streets ensures sunlight only for a minimum number of dwellings.... And so we come to this dismal result: one facade out of four, whether it faces the street or the courtyard, is oriented to the north and never knows the sun, while the other three, owing to the narrowness of the streets and courts they face and to the resulting shadow are half deprived of sunlight also. (Ibid., para. I 7)

and

The alignment of dwellings along transportation routes must be prohibited. (Ibid., para.27)

\section{Demolition of historic fabric and pattern.}

Apart from a few exceptional cultural relics, historic buildings and neighbourhoods were to be torn down to make way for more hygienic and functionally efficient architecture that was more appropriate to the age of machinery and industrial production. Under no circumstances must any stylistic features from the past be re-used in the new architecture, as it would amount to "mingling the false with the genuine."

The destruction of the slums around historic monuments will provide an opportunity to create verdant areas. In certain cases, it is possible that the demolition of unsanitary houses and slums around some monument of historical value will destroy an age-old ambience. This is regrettable, but it is inevitable. The situation can be turned to advantage by the introduction of verdant areas. There, the vestiges of the past will be bathed in a new and possibly unexpected ambience, but certainly a tolerable one, and one from which the neighbouring districts will amply benefit in any event. (Ibid., para.69)

and

Unsanitary blocks of houses must be demolished and replaced by green areas: the adjacent housing quarters will thus become more sanitary. An elementary knowledge of the principal notions of health and sanitation is sufficient to detect a slum building and to discriminate a clearly unsanitary city block. These [70] blocks must be demolished, and this should be an opportunity to replace them with parks which, at least in regard to the adjacent housing quarters, will be the first step toward improved health conditions. (Ibid., para.36)

and

The practice of using styles of the past on aesthetic pretexts for new structures erected in historic areas has harmful consequences. Neither the continuation of such practices nor the introduction of such initiatives will be tolerated in any form. Such methods are contrary to the great lesson of history. Never has a return to the past been recorded, never has man retraced his own steps. The masterpieces of the past show us that each generation has had its way of thinking, its conceptions, its aesthetic, which called upon the entire range of the technical resources of its epoch to serve as the springboard for its imagination. To imitate the past slavishly is to condemn ourselves to delusion, to institute the "false" as a principle, since the working conditions of former times cannot be recreated and since the application of modern techniques to an outdated ideal can never lead to anything but a simulacrum devoid of all vitality. The mingling of the "false" with the "genuine," far from attaining an impression of unity and from giving a sense of purity of style, merely results in artificial reconstruction capable only of discrediting the authentic testimonies that we were most moved to preserve. (Ibid., para.70) 
The resurgence of public space

5. The city as a technical creation by specialists.

Cities were to be rationally planned through a top-down process, with speed, efficiency, and economies of scale and standardization as over- riding goals. Technical specialists armed with statistical information must control the design and management of the form of cities, through a centralized control process. The rights of private individuals must be subordinated to collective need, as defined and enforced by these specialists.

The program must be based on rigorous analyses carried out by specialists. (Ibid., para.86)

and

The principles of modern urbanism, evolved through the labours of innumerable technicians technicians in the art of building, technicians of health, technicians of social organization - have been the subject of articles, books, congresses, public and private debates. But they still must be acknowledged by the administrative agencies charged with watching over the destiny of cities.... (lbid., para.74)

and

To accomplish this great task, it is essential to utilize the resources of modern techniques, which, through the collaboration of specialists, will support the art of building with all the dependability that science can provide, and enrich it with inventions and resources of the age. The machinist era has introduced new techniques which are one of the causes of the disorder and upheaval of the cities. And yet it is to those very techniques that we must look for a solution to the problem. Modern construction techniques have established new methods, provided new facilities, made new dimensions possible. They have opened an entirely new cycle in the history of architecture. The new structures will be not only of a scale, but also of a complexity unknown until now. In order to fulfil the many-faceted task that has been imposed on him, the architect will have to join with many specialists at every stage of the undertaking. (Ibid., para.90)

and

Private interest will be subordinated to the collective interest. (Ibid., para.95)

and

To pass from theory to action still requires a combination of the following factors: a political power such as one might wish - clear-sighted, with earnest conviction, and determined to achieve those improved living conditions that have been worked out and set down on paper; [and] an enlightened population that will understand, desire, and demand what the specialists have envisaged for it... (Ibid., para.9I)

6. The city as a fixed end state design rather than an open, evolutionary, form-creating process. The goal of design was to create a static solution, rather than to engage a dynamic process. On the contrary, cities were seen as too chaotic and messy, and there was not enough clarity of order.

Plans will determine the structure of each of the sectors allocated to the four key functions and they will also determine their respective locations within the whole. (Ibid., para.78) 
and

It is a matter of the most urgent necessity that every city draw up its program and enact the laws that will enable it to be carried out. Chance will give way to foresight, and program will replace improvisation. (Ibid., para.85)

and

The absence of urbanism is the cause of the anarchy that prevails in the organization of cities and in the equipment of industries. (Ibid., para.94)

The Athens Charter as technical implementation of a fixed political condition We see, then, that the Athens Charter was heavily focused on a machine-like conception of the city, in which clearly identified and segregated parts operated smoothly to produce a desirable urban order. Underlying that conception was a political and economic ideal that was largely static. The role of technical specialists - especially planners and designers - was to execute that agenda, and thereby to achieve the static ideal.

Notably missing from that agenda was a conception of a dynamic co-production of the city, involving other kinds of actors and structures. Once the structure of the city was determined, it would be left to other people merely to populate these spaces, adding their own subsidiary pieces but not fundamentally engaging with the structure of the city or its production.

Unfortunately, while many cities around the world did indeed implement most of the principles of the Athens Charter, many of these interventions were not successful. Especially in the Global South, rapidly urbanising cities with rich historical traditions and cultures were damaged by the inability of modernism to consider how differently people and places are co-produced (as we saw in the example of Brasilia). Even cities whose structure and form as well as culture were appropriate to this socially segregated European imaginary, and found moderate success with the tall building in a park, there are numerous examples of low income towers in the park housing projects that have deteriorated and been torn down (Low 2003, Fennell 2016). Relatively successful examples include Parkchester, a planned middle-class housing complex built in 1939 in New York City's Bronx borough, featuring separated housing areas set in a park setting with functionally separated commercial and transportation corridors.

Another phenomenon is the emergence of informality in previous examples of CIAMinspired plans, such as the previously discussed Brasilia. Although the heavy hand of the original plan restricts what can be built, residents attempt to fill in the vacant spaces between the building and the road, creating small stores underneath the vast towers that allow, and encourage, social interaction on the ground plane. This is an interesting example of the emergence of co-production in spite of, and not because of, the intentions of the original planners.

Most applications of the modernist model, however, have fractured and even in some locations destroyed the historical, indigenous and architectural frameworks of existing cities inserting elements of the Athens Charter to the detriment of citizens and their governments. This has been especially prevalent - and especially troubling - in the developing world. In reaction to the continuing rapid urbanisation in these cities, the New 
Urban Agenda began as a process to reconsider these modernist principles, and replace them with ideas that would foster social justice, equity, and cohesion, as part of a more sustainable form of urbanisation, in what are often culturally and social diverse locations around the globe.

Ironically, given its original socialist aspirations, the CIAM model frequently found its most robust successes within capitalist and neoliberal economies, often among those with decidedly anti-socialist political views. One of the most important initial successes of the CIAM leadership was in the United States, under the patronage of the Rockefeller family of New York, the Armour family of Chicago, and other private interests. At the same time, American companies including Shell Oil, General Motors and others, ran a relentless advertising campaign to promote the car-centred vision of the CIAM model. Clearly these companies also had a strong interest in controlling the outcome of urbanisation, and there was little scope for concepts of co-production in their aspirations (Peattie 1970).
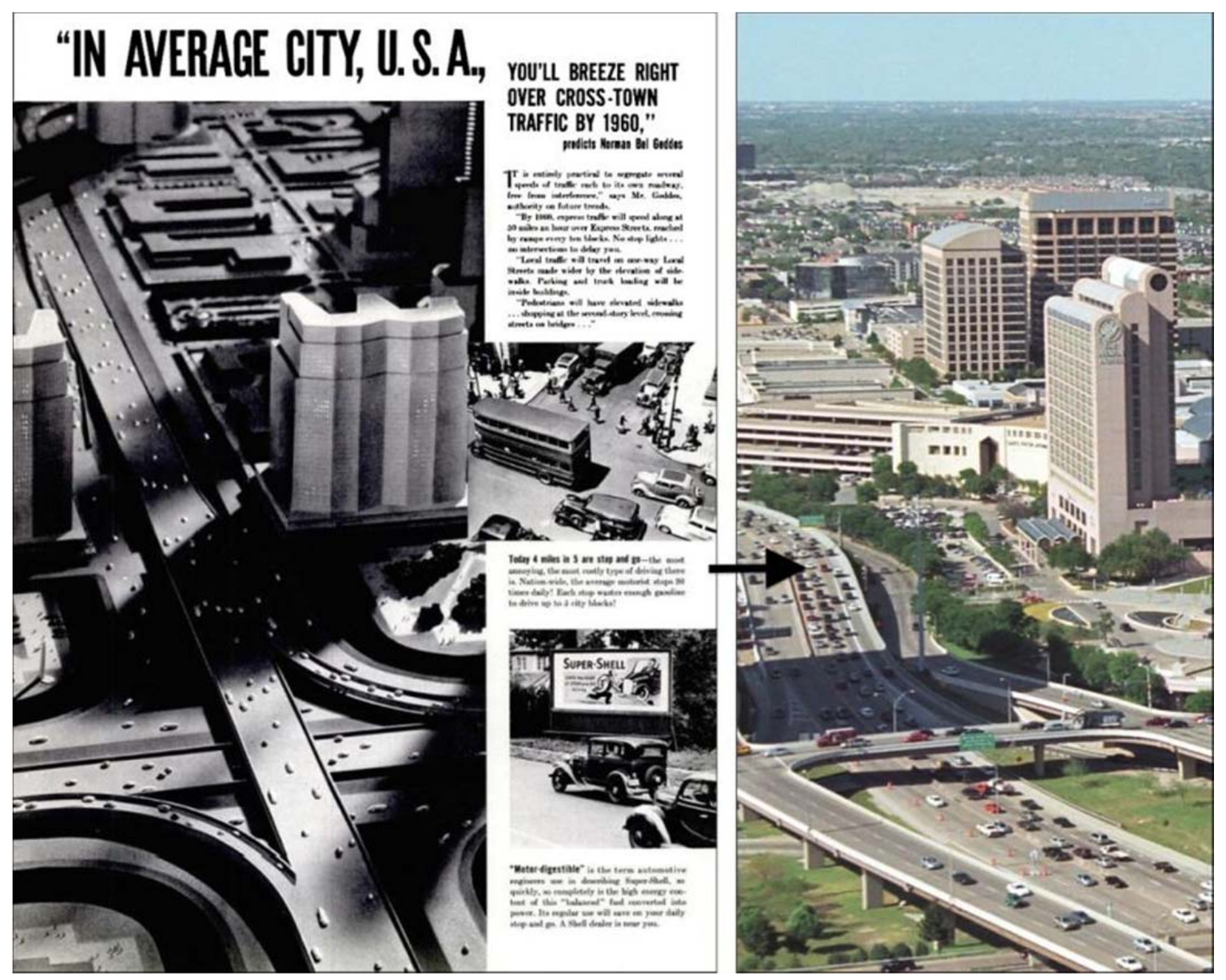

Figure I. (Left) 1935 advertisement in Life magazine by Shell Oil Company, promoting the CIAM model of urbanisation, which was later built in American cities like Dallas, Texas (right). 


\section{Co-production and public space in the Athens Charter}

As we have seen, a notable commonality across the six key points is a singular conception of the public spaces of cities, as static receptacles for discrete activities with no affordance of interaction. No longer could public spaces rely upon different uses and interactions at different times of the day, thanks to function-based zoning. No longer did the street serve as important site of mixing public spaces in its own right, since pedestrians were to be segregated from traffic and indeed, largely removed from the ground plane (Sennett, 2017). Public spaces associated with set-off buildings tended to take on the characteristic of semi-privatized spaces rather than spaces of social encounter, commerce and sociality. Public spaces as layers of the present and the past were largely eliminated, since there was a clear separation of those public spaces that are historic monuments, and those that are newly built on demolished sites. Ultimately, both the design by specialists of a fixed and planned "end state" excluded the ongoing participation of residents as participants in the public space.

The architect and the planner along with those who financed, governed and managed the city - whether capitalist or socialist - became the sole authorities in what would make a good and just city.

\section{The 2016 New Urban Agenda}

In October 2016, The United Nations convened Habitat III, the third "United Nations Conference on Housing and Sustainable Urban Development". The outcome document of this conference was titled "New Urban Agenda: The Quito Declaration on Sustainable Cities and Human Settlements for All." This document is intended to govern international urban development policy for the next two decades (United Nations, 2017). The first Habitat conference took place in Vancouver, Canada in 1976, and focused primarily on issues of rural poverty (United Nations, 1976). Habitat II, in Istanbul, Turkey, focused more specifically on sustainable urban development and ecological issues (United Nations, 1996). The focus of Habitat III was more specifically on the quality of cities, particularly in the context of rapid urbanisation, and in particular, issues of segregation, inequality and environmental deterioration. As the New Urban Agenda notes in its introductory passages:

Since the United Nations Conferences on Human Settlements in Vancouver, Canada, in 1976 and in Istanbul, Turkey, in 1996, and the adoption of the Millennium Development Goals in 2000, we have seen improvements in the quality of life of millions of urban inhabitants, including slum and informal-settlement dwellers. However, the persistence of multiple forms of poverty, growing inequalities and environmental degradation remain among the major obstacles to sustainable development worldwide, with social and economic exclusion and spatial segregation often an irrefutable reality in cities and human settlements. (United Nations, 2017, para.3)

Like the Charter of Athens, the New Urban Agenda is long and comprehensive, comprising 175 paragraphs and over 14,000 words (whereas the core declaration of the Charter of Athens is closer to 16,000 words). The New Urban Agenda is less formally structured by topic than the Charter of Athens, but it does have an overall structure of parts, as follows: 
- Quito Declaration on Sustainable Cities and Human Settlements for All (Introduction) (10 paragraphs)

- Our shared vision (3 paragraphs)

- Our principles and commitments (2 paragraphs)

- Call for action (8 paragraphs)

- Transformative commitments for sustainable urban development (39 paragraphs)

o Environmentally sustainable and resilient urban development (I8 paragraphs)

- Effective implementation (4 paragraphs)

o Building the urban governance structure: establishing a supportive framework (8 paragraphs)

- Planning and managing urban spatial development (33 paragraphs)

o Means of implementation (35 paragraphs)

- Follow-up and review ( 15 paragraphs)

The New Urban Agenda recognizes the challenges of implementation, even as it also recognizes the great opportunities that cities represent for human development. As the document states in its introductory section:

We are still far from adequately addressing these and other existing and emerging challenges, and there is a need to take advantage of the opportunities presented by urbanisation as an engine of sustained and inclusive economic growth, social and cultural development, and environmental protection, and of its potential contributions to the achievement of transformative and sustainable development. (Ibid., para.4)

The key elements of the New Urban Agenda that differ most significantly with the key elements of the Charter of Athens can be summarized as follows:

\section{Mixed use instead of function-based zoning.}

Work, home, recreation and transport are to be integrated within mixed-use neighbourhoods.

We commit ourselves to promoting the development of urban spatial frameworks, including urban planning and design instruments that support ...appropriate compactness and density, polycentrism, and mixed uses (Ibid., para.5I)

and

We will promote integrated urban and territorial planning, including... mixed social and economic uses (Ibid., para.98)

\section{Mixed streets instead of functionally restricted streets.}

The design of streets aims to create pedestrian-centred public space with mixed multimodal transportation centred on the pedestrian. Streets are critical public spaces that allow the mixing of diverse peoples.

We commit ourselves to promoting safe, inclusive, accessible, green and quality public spaces, including streets ... that are multifunctional areas for social interaction and inclusion, human health and well-being, economic exchange and cultural expression and dialogue among a wide diversity of people and cultures, and that are designed and managed to ensure human 
development and build peaceful, inclusive and participatory societies, as well as to promote living together, connectivity and social inclusion. (Ibid., para.37)

and

We will support the provision of well-designed networks of safe, accessible, green and quality streets and other public spaces that are accessible to all and free from crime and violence, including sexual harassment and gender-based violence, considering the human scale...(Ibid., para. 100)

\section{Integration instead of segregation of buildings.}

Urban design must create coherent public spaces by fronting and activating the edges of buildings, and thereby avoid what Jane Jacobs derisively called the "project land oozes" of CIAM-based planning. This is critical to achieve a successful, active pedestrian and public realm:

We will support ... measures that allow for the best possible commercial use of street-level floors, fostering both formal and informal local markets and commerce, as well as not-for-profit community initiatives, bringing people into public spaces and promoting walkability and cycling with the goal of improving health and well-being. (Ibid., para. I00)

4. Adaptive re-use, not demolition, of historic fabric and pattern, including informal areas. The first priority is to re-use existing assets, including regeneration of historic buildings and informal urban patterns. The tangible (buildings) and intangible (knowledge) forms of heritage are not relics of the past to admire from afar, but a living resource that contributes to social participation, value creation, and sustainable development today:

We commit ourselves to the sustainable leveraging of natural and cultural heritage, both tangible and intangible, in cities and human settlements... to safeguard and promote cultural infrastructures and sites, museums, indigenous cultures and languages, as well as traditional knowledge and the arts, highlighting the role that these play in rehabilitating and revitalizing urban areas and in strengthening social participation and the exercise of citizenship. (Ibid., para.37)

and

We will promote planned urban extensions and infill, prioritizing renewal, regeneration and retrofitting of urban areas, as appropriate, including the upgrading of slums and informal settlements, providing high-quality buildings and public spaces... while preserving cultural heritage.... (Ibid., para.97)

and

We will include culture as a priority component of urban plans and strategies in the adoption of planning instruments, including master plans, zoning guidelines, building codes, coastal management policies and strategic development policies that safeguard a diverse range of tangible and intangible cultural heritage and landscapes, and will protect them from potential disruptive impacts of urban development. (Ibid., para. I24) 
The resurgence of public space

We will support the leveraging of cultural heritage for sustainable urban development and recognize its role in stimulating participation and responsibility. (Ibid., para. I25)

\section{The city is co-created by all citizens, and is not merely a technical creation by specialists and their institutions.}

The city is seen as a kind of public platform that offers its citizens the opportunity to engage in a diverse range of private and public actions that shape the city, its structures and its life. The public and private spaces of the city are "socially produced," that is, generated through social processes, and not solely through the actions of specialists and their institutions.

We commit ourselves to promoting national, subnational and local housing policies that support... enabling the participation and engagement of communities and relevant stakeholders in the planning and implementation of these policies, including supporting the social production of habitat... (Ibid., para.3I)

and

We envisage cities and human settlements that: (b) Are participatory, promote civic engagement, engender a sense of belonging and ownership among all their inhabitants, prioritize safe, inclusive, accessible, green and quality public spaces (Ibid., para. I3)

and

We commit ourselves to working towards an urban paradigm shift for a New Urban Agenda that will: (a) Readdress the way we plan, finance, develop, govern and manage cities and human settlements (Ibid., para. I5)

and

We share a vision of cities for all, referring to the equal use and enjoyment of cities and human settlements, seeking to promote inclusivity and ensure that all inhabitants, of present and future generations, without discrimination of any kind, are able to inhabit and produce just, safe, healthy, accessible, affordable, resilient and sustainable cities and human settlements to foster prosperity and quality of life for all. We note the efforts of some national and local governments to enshrine this vision, referred to as "right to the city", in their legislation, political declarations and charters. (Ibid., para. II)

6. The city is not a closed "end state" but an open-ended evolving structure that provides the means to adapt to the evolving needs of citizens and communities, including support for informal growth processes. In addition, buildings are not static structures but, as they grow older, they may be adapted as needs change. The city does not seek one static "new" architecture, but rather, a kind of "fugue" of tangible and intangible cultural heritage, inter-woven with new technologies and techniques.

We will encourage the development of policies, tools, mechanisms and financing models...that would address the evolving needs of persons and communities, in order to improve the supply of housing... This will include support to incremental housing and self- build schemes, with special attention to programmes for upgrading slums and informal settlements. (Ibid., para. I07) 
and

We will promote innovative and sustainable use of architectural monuments and sites, with the intention of value creation, through respectful restoration and adaptation. We will engage indigenous peoples and local communities in the promotion and dissemination of knowledge of tangible and intangible cultural heritage and protection of traditional expressions and languages, including through the use of new technologies and techniques. (Ibid., para. 125)

\section{Public space revived}

As we saw with the Charter of Athens, each of these six points has profound implications for the role of public space, and its co-production, within urban form. Public space (crucially including the street) is an arena for mixing of diverse uses, activities and people. Walkable public space (again, crucially including streets) plays a central role in a truly multi-modal transportation system. Historic public spaces, and their adjacent buildings, are often important generators of cultural and economic wealth. Co-creation of the city assumes the ability to operate adjacent to or within streets and other public spaces. Finally, the idea of an evolutionary and "open" city presupposes openness of the public space networks through which its co-creators must move and interact.

The importance of public space in the New Urban Agenda is highlighted by its inclusion in no fewer than eight paragraphs, including discussion of "streets as public spaces," public spaces as "drivers of social and economic development," "well-connected and welldistributed networks" of public space, and other passages that make clear the central priority of public space within the urban form of cities in the coming decades.

\section{Summarizing the differences}

We can now re-state these six points of divergence as a series of topics within the process of urbanisation, urban form and public space:

I. Zoning of urban elements. Are the elements neatly segregated according to Le Corbusier's ideas of "functionalism" - that is, a machine-like conception of the rational segregation of parts of the city, to aid in efficiency and economies of scale? Or is there a considerable mingling of uses, which can change and evolve over time? Does zoning instead focus on a supportive physical form that accommodates a (changing) diversity of uses, connected through public space networks?

2. Treatment of streets. Are the different streets assigned to strict uses by vehicles of only a certain kind and speed, with pedestrians removed to their own pathways? Or is there a mix of modes on most streets, welcoming pedestrians as well as vehicles, and mitigating the impacts of each on the other through more careful design? Are streets treated as public spaces in their own right?

3. Treatment and placement of buildings. Are buildings removed from streets, and loosely grouped within "superblocks" of limited access and separate pedestrian paths? Are they treated as standalone "object-buildings" within loose verdant settings? 
The resurgence of public space

Or are buildings placed to frame, define and activate public spaces, including streets?

4. Treatment of historic structures and patterns. Are older buildings and patterns regarded as irrelevant to contemporary challenges and not to be conserved, with the exception of a few representative specimens of historical interest only? Or is heritage conserved and re-used, in both tangible (buildings) and intangible (knowledge, culture) forms? Are lessons learned and re-applied from the successful (and unsuccessful) patterns of the past? Is history seen as a kind of "fugue" of old and new, continuously weaving together? Are historic public spaces, including street patterns, conserved and extended?

5. The role of specialists in relation to others. Is the creation of the city an exclusive domain of technical specialists, to the exclusion of other co-creators and forces of informality? Are these forces of informality suppressed and even destroyed? Or is the city treated as a continuous co-creation by many actors operating within or adjoining public spaces, guided by a "polycentric governance" at formal and informal levels?

6. The role of time and evolution. Are the designs of the city conceived as unchanging works of art and engineering targeted to human needs as defined at a fixed point in time?

Or is the city conceived as a "complex adaptive system" that is continuously transforming, guided by design frameworks and strategies into more preferred conditions? Is the public space system an integral part of this evolutionary urban system?

We can summarize these points in the following table:

\begin{tabular}{|l|l|l|}
\hline Topic & \multicolumn{1}{l}{ Athens Charter of 1933 } & \multicolumn{1}{l}{ New Urban Agenda of 2016 } \\
\hline 1. Zoning of Urban Elements & $\begin{array}{l}\text { Segregated according to use and } \\
\text { "Functionalism" }\end{array}$ & $\begin{array}{l}\text { Mixed uses are encouraged while } \\
\text { regulation focuses on form }\end{array}$ \\
\hline 2. Treatment of Streets & $\begin{array}{l}\text { Streets are strictly segregated by } \\
\text { vehicle speed, and pedestrians are } \\
\text { prohibited }\end{array}$ & $\begin{array}{l}\text { Streets are places of multi-modal } \\
\text { transportation and public spaces, } \\
\text { welcoming pedestrians }\end{array}$ \\
\hline 4. Treatment of Historic Structures and Patterns & $\begin{array}{l}\text { Most historic structures are } \\
\text { demolished, while a few } \\
\text { representative monuments are } \\
\text { retained; knowledge of traditional } \\
\text { patterns is regarded as obsolete }\end{array}$ & $\begin{array}{l}\text { Both tangible (buildings, } \\
\text { monuments) and intangible } \\
\text { (knowledge, patterns) heritage is } \\
\text { conserved and re-used, often } \\
\text { combined with new technolgies } \\
\text { and approaches }\end{array}$ \\
\hline 5. Role of Specialists in Relation to Others & $\begin{array}{l}\text { The city is a creation of specialists } \\
\text { (economic, political, technical, } \\
\text { design) }\end{array}$ & $\begin{array}{l}\text { The city is a co-creation of many } \\
\text { actors at many levels, including } \\
\text { informal processes }\end{array}$ \\
\hline 6. Role of Time and Evolution in the City & $\begin{array}{l}\text { The city is a static work of art and } \\
\text { engineering, aimed at pre-defined } \\
\text { human needs at a fixed point in time }\end{array}$ & $\begin{array}{l}\text { The city is a complex adaptive } \\
\text { system that must be continually } \\
\text { engaged by design to transform } \\
\text { toward more "preferred" states }\end{array}$ \\
\hline
\end{tabular}

Table I. Six normative topics of urbanism 


\section{Changes in urban science since the Athens Charter}

In the intervening years between the CIAM/Le Corbusier document and the UN document, there have of course been overwhelming changes in the sciences, and as a direct consequence, in our understanding of technology, design, and urbanism. In 1933, the design theorist Herbert Simon had not yet formulated his definition of design as a process of "changing existing conditions into preferred ones" - a very different definition indeed from the more determined, "tabula rasa" approach of the early $20^{\text {th }}$ Century (Simon, 1988).

Nor did we understand, in 1933 - or indeed 1943 - the sheer complexity of urban processes, and the capacity of networks of people and processes to create "emergent" results with important benefits. We had little grasp of the potential power of "selforganization," or what Jane Jacobs later referred to as "organized complexity" - and the role of myriad people in co-producing more vibrant, creative and prosperous cities (Bettencourt, 2013).

We also did not understand the evolutionary nature of history, or the occasional value of recapitulation in finding the best available design alternatives, from whatever time or place. From this perspective, it is now looking remarkably unwise to have cut ourselves off from this vast repository of well-evolved design solutions, which seem to offer so many promising solutions to the more universal problems of living well together in settlements (Ben Hamouche, 2009).

Nor did we understand what Jacobs later referred to as "border vacuums" - the urban dead zones around large discontinuous superblocks - or the deadening power of isolated object-buildings (Jacobs, 1961).

Prior to 1943, ideas about transportation treated streets more like wastewater pipes, neatly segregated by type and rationally engineered to handle fixed magnitudes of (car) flow. We didn't understand that demand is elastic and people can choose to drive more or less, so that adding capacity to ease congestion can result in "induced demand" and "Braess' paradox" - actually making traffic move even more slowly (Pas and Pricipio, 1997).

Most fundamentally, we failed to understand the importance of diversity and mixing - of people, pedestrians and cars, and uses. That is because we failed to understand, or didn't yet understand, how networks actually work to create interactions and catalytic benefits. The science of networks, applied to economies, resource flows, and social patterns, barely existed in 1943, and had no counterpart in the architecture world (Batty, 2013). It is telling that the 1933 Charter of Athens proceeded on a remarkably limited and flawed picture of the world, stated concisely by Le Corbusier:

The Fourth Congress of the CIAM, held in Athens, has proceeded from this postulate: sun, vegetation, and space are the three raw materials of urbanism. (Le Corbusier, 1943, para. I2)

This statement is understandable from the perspective of someone who was desperate to flee the manifest problems of $19^{\text {th }}$ Century cities, and especially their slum areas: poor sanitation, over-crowding, lack of access to sun and openness. Yet from today's perspective it is simply indefensible. The three elements it does mention are important to include, but hardly universal fundamentals. After all, in hot climates, sun is to be largely 
avoided, not sought; and vegetation and space (by which Le Corbusier means spaciousness) are occasionally but not always appropriate.

Le Corbusier in particular had a well-expressed personal predilection against "huddled" cities, and a fascination with grander, more spacious urbanism - which for him necessarily meant a more disconnected and machine-dependent urbanism (Le Corbusier, 1924). It was also an urbanism at a far grander scale than that of human beings. Today, as we are witnessing, this is also an extremely resource-intensive urbanism - and as many argue, an unsustainable one (Farr, 20II; Talen, 20II).

Most revealing, the three "raw materials of urbanism" overlook the most important element of all - the human being. We now see this human being as a creature with agency, with need of connections, and with need to control and modulate these connections, within networks of social, economic and environmental activity. This human being is not a passive consumer of "sun, vegetation, and space."

The vision of Le Corbusier and the other architects of CIAM is expressed well by this drawing by Adolf Bayer in 1948 - a kind of propaganda piece meant to influence post-war reconstruction, as indeed it and other similar materials did.

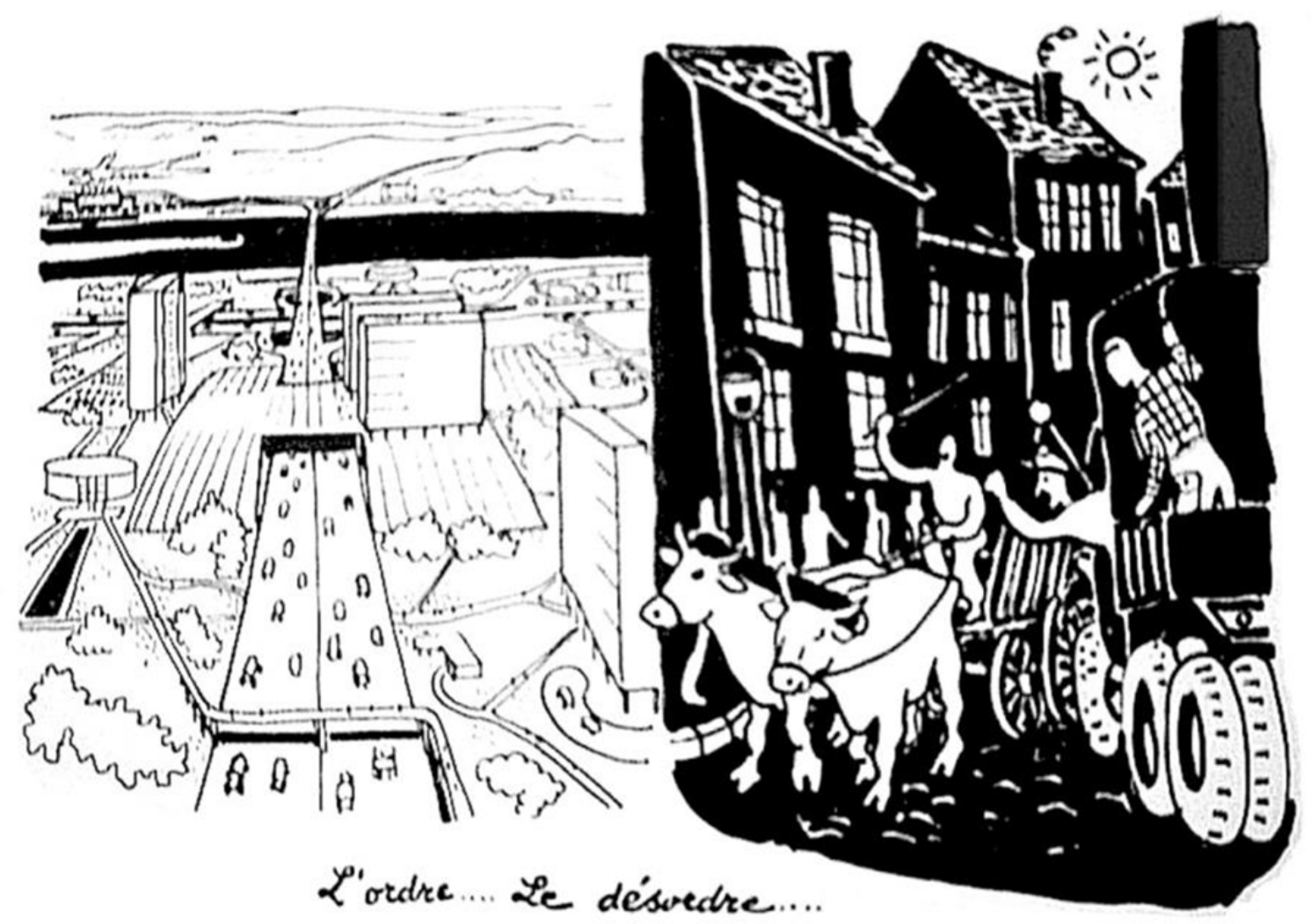

Figure 2. L'ordre... Le désordre, by Adolf Bayer, 1948. On the right is the dirty, dark, crowded, messy traditional city, mired in the filth of animals. On the left is the wonderfully clean, sanitary, mechanically ordered city, with freeways whisking fast automobiles to wherever they may want to go.

Notice what happens to the proximity of human beings in moving from the right-hand traditional city to the left-hand CIAM one. They are mostly isolated into small capsules - 
automobiles, work spaces, home apartments. No longer are there complex activities along streets lined with shops and services; no more are people connecting with one another, carrying out plans, forming webs of interaction and vitality. Where pedestrians exist, they are left to trudge along long empty pathways, offering no detail, no intricate change of scenery. They appear as little more than ants, lost in a world of sweeping gigantism.

What is even more remarkable is that in the drawing to the left, there is virtually no public space as such. To be sure, there are plazas and parks, but they are severed from the tissue of connection to other urban elements. They have few activities at their edges, few pedestrians who pass by or through them, and little to generate active use. They are mostly "for looks" - part of a static tableau.

Yet it is precisely this realm of public space where "cities for all" manifests most powerfully - where people may encounter one another, interact, trade, advocate, and find adjacent private property where they may carry out their own plans and aspirations. This does not happen and cannot happen in the gigantic structures of the CIAM/Bayer drawing, with their static designs and their institutional controls. It can only happen along active, mixed, multi-modal streets and other truly public spaces.

There is one other important point to acknowledge. As the last half-century has shown, it is possible to wholly replace this realm of public space, with its natural benefits of agglomeration, networks of propinquity and catalytic interaction, with an artificial network of automobiles, conference rooms, telephones, and the Internet. However, there are two main drawbacks with this approach. One, it is resource-intensive, and, as many argue, ultimately not sustainable. Two, it is exclusionary, and largely leaves the poor and the marginal out of the network. This is bad for the poor, and ultimately, bad for everyone else (Bettencourt, 20I3).

A similar caution must be voiced about so-called "smart" cities. Indeed, as a recent editorial in the New York Times by author Emily Badger points out, there are dangers in the call of smart cities that harken back to the CIAM conception of stark "efficiency" and "function," as well as digitally based designs that start from scratch. Indeed, one interviewee from a start-up accelerator suggested that historical awareness and traditional knowledge only get in the way of tech-based breakthrough ideas. From Badger's article:

To planners and architects, all of this sounds like the naiveté of newcomers who are mistaking political problems for engineering puzzles. Utopian city-building schemes have seldom succeeded. What we really need, they say, is to fix the cities we already have, not to set off in search of new one. But it is hard to overstate the degree to which these tech entrepreneurs are looking at the world in ways that would be almost unrecognizable to anyone already working on urban problems..." (Badger 2018:2).

As Bettencourt and others have shown, a city that excludes large portions of its urban population will under-perform, relative to cities that are more inclusive. This is not only because the excluded populations will tend to demand increasing levels of social service, policing etc. More important, urban economic networks, like other networks, benefit from greater connectivity of larger numbers of nodes, following what is known as "Metcalf's Law". The more connected are members of an urban economy, other things 
held equal, the more the economy is likely to perform optimally (Bettencourt and Lobo, 2016).

This key conclusion offers a powerful motivation for municipal governments and other leaders to make (often difficult) changes in their urban structure to be more accessible, more connected and more diverse. The result not only provides benefits for social justice and equity - it offers benefits for everyone's "bottom line."

\section{Conclusion}

The collection of papers in this edition of The Journal of Public Space - and indeed, the existence of the journal itself - are a reflection of the renewed vitality of public space research, and the new relevance of public space in international policies like the New Urban Agenda.

It should also be clear from the previous discussion, however, that achieving the normative goals of New Urban Agenda - including its public space goals - will require a markedly different set of urban models, able to replace those that have been dominant since the post-war era - those that were outlined in the Athens Charter. Among them we can include the segregated-use zone, the segregated street, the superblock, the "urban renewal" (demolished) historic area, structures created solely by specialists, and "static" engineered elements. Implementation will require, among other things, that we identify alternate models, and the specific characteristics that they will require.

In fact, these models are already well-established in older parts of many cities - namely, mixed-use zones, multi-modal streets, buildings aligning with streets, neighbourhoods that incorporate and build upon historic patterns, "emergent" urban areas that are co-created by many people, and structures that reflect an ongoing, dynamic approach to design. The common objection to these examples is "yes, but that was long ago, and the world's economy and society does not operate in that way any longer."

We will need to examine modern examples of cities that operate successfully as prosperous and creative contributors to the global economy, while also demonstrating the different urban models that are called for in the New Urban Agenda. That is a task that the authors hope to take up, with others, in future research. We can also point to early examples of such assessments (e.g. Mehaffy, 20I7, Chapter V.I).

More deeply, we must examine not only the forms of these cities, but the processes that produce them - including co-production processes. Clearly we have seen that the New Urban Agenda represents a historic departure from previous conceptions of the role of non-specialists, including citizens and informal entities, in the co-production of urban structure and especially, public space. We have argued that this affordance is an essential and defining characteristic of the New Urban Agenda, and a marked contrast from the Charter of Athens.

We have also described the central role of public space itself which, through its structure and management, must play an important role in providing the capacity for co-production of the city. For those working to implement the New Urban Agenda, this topic - the structure of public space, and the processes by which it is created and maintained by many actors - demands much more careful study and research. As Joan Clos said, in the end "the relationship in a city between public space and buildable space... is the art and science of building cities." 
A further significant remaining challenge will be to identify the tools and strategies by which these alternative models and processes may be implemented in both new urbanisation projects, and in the crucial retrofits of large existing areas built during the post-World War II period, including many suburbs. There is currently an enormous "lock-in" of existing codes, laws, standards, rules, tax policies, and other incentives and disincentives for contemporary urban development - what we may think of as a kind of "operating system for growth." This system, and its myriad sub-systems, will also have to be extensively reformed. Strategies and incentives will need to be found for doing so, before we can expect feasible large-scale implementation of the New Urban Agenda. This is certainly a daunting challenge. However, we can find considerable encouragement in the same lessons of history emerging in the wake of the Charter of Athens - not only the profound mistakes of that era, but its successful and even breathtaking implementation as well. For that radical transition also required major systemic changes, including new codes, laws, standards, rules, and incentives. Those changes proceeded, and whatever their many faults, we can readily see that the transformation was brilliantly effective. Then as now, the most important first step was to identify and embrace the new normative models. Then as now, we had the responsibility to make real and profound choices that would shape our urban future, for better or worse, for generations to come.

$$
* * * * * * *
$$

There is one respect in which our approach today must be radically different from the approach taken in developing the Charter of Athens. While the members of the CIAM felt free to make their doctrinal pronouncements ex cathedra, we are compelled today to base our reforms upon actual evidence, and upon an understanding of the varying demands of context. Therefore we must develop and share research evidence on what actually works and why, what is important and why, and how successful strategies in one place can be translated into new applications in another. That is the basis of the new research agenda that we need for public space.

The authors in this volume offer stellar examples of this kind of research. In the first research article J. Antonio Lara-Hernandez, Alessandro Melis, and Claire M. Coulter examine the temporary use of streets as public spaces in Mexico City, and the tension that often exists between local traditions of use with existing legislation. They outline the history of laws and regulations on street life and transportation planning and then contrast these legislative interventions with everyday patterns of use and appropriation of the street by neighbourhood groups and individuals. This comparison illuminates the municipality's preference for transit and tourist uses over local street-vending, socializing and religious processions and underscores some of the difficulties of implementing the New Urban Agenda in ways that speak to both governmental and residential needs and benefits.

The second and third research papers focus on finding ways to assess and measure public space use and sociability. Stephen Appiah Takyi, Andrew D. Seidel, and Jones Kweku Adjei are interested in who uses public parks, and at what intensity, with two case studies from Vancouver, Cananda. The contrasting cases suggests ways that Park administrator and policy makers can assess specific needs by neighbourhood providing more effective use and satisfaction with park amenities. Thomas Oram, Ahmad Jehan Baguley, and Jack Swain 
are also concerned with how public space accommodates users, in this case focusing on the effects of outdoor seating on sociability in Brisbane, Australia. They conclude that more and better seating that includes shade and shelter would be necessary to improve the social use of the Queen Street Mall. Their interviewee quotes reflect the downturn of the use of this space and its focus on commercial activities to the exclusion of other social uses.

The final two research articles offer programmatic recommendations based on observations of the increasing digitalization and technification of public space. Kevin Leyden, Benita Lipps, and Namita Kambli question the "smart city" model, and ask how we can create more livable, people-friendly places. They draw together findings from researchers, city planners, architects, public officials, urban activists, businesses, and NGOs from 30 countries to offer a comprehension, albeit, idealized set of propositions that can guide smart cities in the future. Kylie Budge, on the other hand, examines how different kinds of public spaces within a museum setting - an important but sometimes overlooked institutional public space - motivate people to behave differently, particularly in their activities on social media. By examining Instagram posts from the Cooper Hewitt Design Museum immersive space, Budge suggests that the role of the museum as public space may be changing and offers ways for visitors to communicate the emotional importance of a place as well as creating a play-based public through social media. The issue concludes with three viewpoint pieces. Tom Rankin looks at how art can serve as a catalyst to activate public space, with a case study of artist William Kentridge's Rome project 'Triumphs and Laments'. Robbie Warin explores the case study of "The Undercroft" skateboard park on London's Southbank, and the attempt to relocate it - an effort that failed to recognize the lived experiences of the individuals involved, and "their desire to be included in the ongoing production of public space, and therefore deeply embedded within their own individual and collective senses of citizenship." Finally, Cristina Cassandra Murphy takes up the extremely timely issue of migration, and the need for "in-between" public spaces that can be shared between migrants and locals, with explorations in Bogota, Tucson, Baltimore, and Rotterdam.

All of these studies have a number of features in common. They are grounded in detailed field studies of people actually experiencing and interacting with public spaces; they extract detailed lessons about the dynamics of public spaces; they are drawn from cities around the world; and they contribute to a body of lessons that can be translated and adapted to many other locations. They are, in short, at the vanguard of a new generation of public space research, contributing to a new and better generation of public spaces and along the way, to the timely implementation of the New Urban Agenda.

\section{Acknowledgments}

This work was generously funded by KTH Royal Institute of Technology and the Ax:son Johnson Foundation in Stockholm, Sweden. 


\section{References}

Badger, E. (2018). Tech Eyes the Ultimate Start-Up: An Entire City. New York Times Sunday February 25, p. 2. Sunday Review Section.

Batty, M. (20I3). The new science of cities. Boston: MIT Press.

Ben-Hamouche, M. (2009). Complexity of urban fabric in traditional Muslim cities: Importing old wisdom to present cities. Urban Design International, I4(I), 22-35.

Bettencourt, L. M. A. (20/3). The kind of problem a city is. Santa Fe Working Paper, Santa Fe Institute. Available on the Web at https://sfi-edu.s3.amazonaws.com/sfiedu/production/uploads/sfi-com/dev/uploads/filer/fa/f6/faf6|4|8-fc4f-42d5-8c28dfI 197a390/8//3-03-008.pdf

Bettencourt, L. M., \& Lobo, J. (2016). Urban scaling in Europe. Journal of The Royal Society Interface, 13(I 16). DOI: https://doi.org/10.1098/rsif.2016.0005

Clos, J. (2016). "We have lost the science of building cities", Interview in The Guardian, I8 April 2016. Accessed on the Web December 4, 2017 at https://www.theguardian.com/cities/2016/apr//8/lost-science-building-cities-joan-clos-unhabitat

Congress for the New Urbanism (2018). The Charter of the New Urbanism. https://www.cnu.org/who-we-are/charter-new-urbanism (accessed I5 April 2018).

Farr, D. (20I I). Sustainable Urbanism: Urban design with nature. New York: John Wiley \& Sons.

Fennell, C. (2015) Last Project Standing: Civics and Sympathy in Post-Welfare Chicago. Minneapolis: University of Minnesota Press

Harvey, D. (1990). The Condition of Postmodernity. Oxford: Blackwell

Harvey, D. (2003) Paris, Capital of Modernity. New York and London: Routledge.

Holston, J. (1989). The Modernist city: An Anthropological Critique of Brasilia. Chicago: University of Chicago Press. 
The resurgence of public space

Jacobs, A., \& Appleyard, D. (1987). Toward an urban design manifesto. Journal of the American Planning Association, 53(I), I I 2-I 20.

Le Corbusier (1924). Vers une Architecture. John Rodker Publisher, London (Reprinted I93I).

Le Corbusier (1943). La Charte d'Athènes. Paris: Éditions Minuit.

Low, S. (2003). Behind the Gates: Life, Liberty and the Pursuit of Happiness in Fortress America. New York: Routledge.

Pas, E. I., \& Principio, S. L. (1997). Braess' paradox: Some new insights. Transportation Research Part B: Methodological, 3 I (3), 265-276.

Peattie, L. (1970) The View from the Barrio. Ann Arbor: University of Michigan Press.

Sennett, R. (2017). "The Open City." In The Post-Urban World: Emergent Transformation of Cities and Regions in the Innovative Global Economy, T. Haas and H. Westlund (eds.). p. 97. New York: Routledge.

Sert, J. L. (1942). Can Our Cities Survive? Cambridge: Harvard University Press.

Simon, H. A. (1988). The science of design: Creating the artificial. Design Issues, 67-82.

Talen, E. (20I I). Sprawl retrofit: sustainable urban form in unsustainable places. Environment and Planning B: Planning and Design, 38(6), 952-978.

UN-HABITAT (2018). The Quito Papers and the New Urban Agenda. New York: Routledge. United Nations ( 1976). The Vancouver Declaration on Human Settlements. Available online at: http://www.unhabitat.org/downloads/docs/924_21239_The_Vancouver_Declaration.pdf United Nations (1996). Istanbul Declaration on Human Settlements. Available online at: http://www.unhabitat.org/content.asp?.cid $=2072 \&$ catid $=10 \&$ typeid $=25 \&$ subMenuld $=0$ United Nations (2017). Resolution adopted by the General Assembly on 23 December 2016: 7I/256, "New Urban Agenda." New York: United Nations (25 January 2017). 